\title{
The Cosmopolitan Turn in Constitutionalism: An Integrated Conception of Public Law
}

\author{
Mattias Kumm \\ New York University, mattias.kumm@nyu.edu
}

Follow this and additional works at: https://www.repository.law.indiana.edu/ijgls

Part of the Constitutional Law Commons, International Law Commons, and the Public Law and Legal Theory Commons

\section{Recommended Citation}

Kumm, Mattias (2013) "The Cosmopolitan Turn in Constitutionalism: An Integrated Conception of Public Law," Indiana Journal of Global Legal Studies: Vol. 20 : Iss. 2 , Article 4.

Available at: https://www.repository.law.indiana.edu/ijgls/vol20/iss2/4

This Symposium is brought to you for free and open access by the Law School Journals at Digital Repository @ Maurer Law. It has been accepted for inclusion in Indiana Journal of Global Legal Studies by an authorized editor of Digital Repository @ Maurer Law. For more information, please contact rvaughan@indiana.edu.

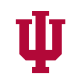

JEROME HALL LAW LIBRARY

INDIANA UNIVERSITY

Maurer School of Law
Bloomington 


\title{
The Cosmopolitan Turn in Constitutionalism: An Integrated Conception of Public Law
}

\author{
MATTIAS KUMM ${ }^{*}$
}

\begin{abstract}
If the point of constitutionalism is to define the legal framework within which collective self-government can legitimately take place, constitutionalism has to take a cosmopolitan turn: it has to occupy itself with the global legitimacy conditions for the exercise of state sovereignty. Contrary to widely made implicit assumptions in constitutional theory and practice, constitutional legitimacy is not self-standing. Whether a national constitution and the political practices authorized by it are legitimate does not depend only on the appropriate democratic quality and rights-respecting nature of domestic legal practices. Instead, national constitutional legitimacy depends, in part, on how the national constitution is integrated into and relates to the wider legal and political world. The drawing of state boundaries and the pursuit of national policies generates justice-sensitive externalities that national law, no matter how democratic, can not claim legitimate authority over. It is the point and purpose of international law to authoritatively address problems of justive-sensitive externalities of state policies. In this way, international law helps create the conditions and defines the domain over which states can legitimately claim sovereignty. States have a standing duty to help create and sustain an international legal system that is equipped to fulfill that function. Only a cosmopolitan state-a state that incorporates and reflects the global legitimacy conditions for claims to sovereignty in its constitutional structure and foreign policy-is a legitimate state.
\end{abstract}

* Inge Rennert Professor of Law, NYU School of Law, Research Professor for "Rule of Law in the Age of Globalization," WZB Berlin \& Humboldt University.

Indiana Journal of Global Legal Studies Vol. 20, Issue 2 (2013)

(C) Indiana University Maurer School of Law 


\section{The Nature of The Debate ABout Constitutionalism}

It has become widespread for international lawyers to describe international law as a whole ${ }^{1}$ or specific international regimes ${ }^{2}$ as a constitutional system. Yet, the use of constitutional language for describing and assessing legal and political practices beyond the state remains a subject of considerable dispute. ${ }^{3}$ Even though the tone and commitments encountered in these debates suggest that something important is at stake, it is not entirely clear what the stakes in the debates about the "magic C-word"4 are. What is this debate about? How should we understand the intensity and commitment characteristically associated with the different positions in this debate?

The disagreement is clearly not empirical. Scholars generally agree about the relevant facts. Nobody doubts that international law evolved considerably after World War II and again after the end of the Cold War. It is not disputed that there are features of international law that bear some resemblance to features associated with domestic constitutional law. In part, these are formal. There are elements of a hierarchy of norms in international law. They range from ius cogens norms-peremptory norms that states may not deviate from even by Treaty-to Article 103 of the U.N. Charter, establishing the priority of the U.N. Charter over other agreements. In part, they are functional: there are multilateral treaties that serve as regime-specific constitutional charters for institutionally complex transnational governance practices. And, in part, they are substantive: human rights

1. For representative examples, see generally JAN KLABBERS ET AL., THE CONSTITUTIONALIZATION OF INTERNATIONAL LAW (2009) (examining to what extent the international legal system has constitutional features comparable to those found in national law); Andreas L. Paulus, The International Legal System as a Constitution, in RULing THE WORLD? CONSTITUTIONALiSM, INTERNATIONAL LAW, AND GLOBAL Governance 69 (Jeffrey L. Dunoff \& Joel P. Trachtman eds., 2009) Thereinafter RULING THE WORLD?] (exploring constitutionalization of the international legal system). For a brief history of constitutional language in international law, see Bardo Fassbender, 'We the Peoples of the United Nations': Constituent Power and Constitutional Form in International Law, in THE PARADOX of Constitutionalism: Constituent Power AND CONSTITUTIONAL FORM 269, 270-73 (Martin Loughlin \& Neil Walker eds., 2007).

2. The focus of the discussions has been on the United Nations, the European Union, the Word Trade Organization, and the international human rights regime. See RULING THE WORLD?, supra note 1, at 113-232.

3. See generally NiCO KRISCH, BEYOND CONSTItUTIONALism: The PluRAlist STRUCTURE OF POSTNATIONAL LAW (2010) (exploring the limitations of the constitutionalist approach to the "postnational" legal order); PETER L. LINDSETH, POWER AND LEGITIMACY: RECONCILING EUROPE AND THE NATION-STATE (2010) (arguing that the supranational framework of the European Union has failed to achieve constitutional legitimacy in its own right).

4. See Eric Stein, The Magic of the C-Word, 18 EUSA REV. 1, 1-5 (2005). 
obligations have long pierced the veil of sovereignty that kept the relationship between the state and its citizens from the purview of international law. The individual has long emerged as a subject of rights and obligations under international law. There are international human rights courts established by treaties that authorize individuals to vindicate their rights before international courts. International law even criminalizes certain types of particularly serious human rights violations. These are features more characteristic of modern constitutional systems than of the traditional paradigm of international law as the law among states.

Constitutional skeptics do not deny that international law exhibits these features, but they insist that this does not justify describing international law in constitutional terms. ${ }^{5}$ Constitutionalism, they insist, is not just connected to certain formalities, functions, or substantive elements. It is connected to something more ambitious. In the tradition of the French and American Revolutions, it is a normatively ambitious project of establishing legitimate authority among free and equals. A trinitarian commitment to human rights, democracy, and the rule of law-we might say-is the dogma of the constitutionalist faith. Legitimate authority in this tradition is widely believed to require "We the People" as the constituent power constituting and limiting public power by way of establishing a constitution that is the supreme law of the land. Constitutionalism is about establishing legitimate supreme authority for free and equals engaged in a collective exercise of self-government. There is no genuine political community on the global level capable of establishing a democratic system of constitutional self-government. And, given the absence of a sovereign state on the global level, the institutional infrastructure that could make such a project effective is also lacking. So, unless someone is engaged in political advocacy for a global constitutional state - a normatively contestable and probably practically futile endeavor for the time being-it is misleading to use the language of constitutionalism to describe international law.

Superficially, there appears to be an easy way to resolve this debate. If this were a mere debate about the use of words, we might simply distinguish between $\mathrm{Big} \mathrm{C}$ and Small $\mathrm{c}$ constitutionalism. Big $\mathrm{C}$

5. Among the most sophisticated skeptics is Dieter Grimm, The Achievement of Constitutionalism and its Prospects in a Changed World, in THE TwiLight of Constitutionalism? 3 (Petra Dobner \& Martin Loughlin eds., 2010). Unlike Grimm, most skeptics are not scholars focused on thinking hard about international law and its theoretical foundations, but constitutional scholars comfortably inhabiting the conceptual and normative domestic constitutional universe in which international law operates primarily as an irritation, perhaps alarming, but probably best ignored. 
constitutionalism-constitutionalism on the domestic level, involving "We the People" establishing a constitutional framework of self-government claiming supreme authority within the framework of the sovereign state-does not exist beyond the state. Small c constitutionalism on the other hand-legal practices sharing some structural features of Big C constitutionalism, but less centralized, more fragmented, imagined without reference to either "We the People" or a sovereign state - can and does exist on the international level. Once such a clarification is made, is there anything more to be said?

But of course, this way of resolving the issue will not satisfy either side. Big C constitutionalists are skeptical about the claims of legitimacy that Small c constitutionalists are implicitly making when they describe international law in constitutional terms. They believe that constitutional rhetoric is used to cover up what they see as a significant normative problem with recent tendencies of international law: the increasing divorce of international law from the legitimating anchor of state consent. ${ }^{6}$ Think of the spreading and increasing power of international institutions, the softening up of the requirements of state practice for the identification of customary international law, the emerging of a plethora of courts and tribunals with the jurisdiction to adjudicate questions of international law, and the increasing tendency of international human rights law to circumscribe how states should relate to their citizens. It appears as if the generation and interpretation of international law is increasingly taken away from the control of states. States are more and more likely to find themselves subject to international legal obligations they have not specifically consented to, and many of those obligations concern regulatory issues or rights questions traditionally addressed only by domestic institutions. For Big C constitutionalists, this is a problem because they believe that the taming of law and politics by way of national constitutional procedures and constraints constitutes an achievement that is now in the process of unravelling, ${ }^{7}$ as international public authority ${ }^{8}$ is increasingly exercised outside of the state. The act of state consent is believed to connect national constitutional values and commitments to the generation of international law, bestowing whatever legitimacy it

6. See Mattias Kumm, The Legitimacy of International Law: A Constitutionalist Framework of Analysis, EUR. J. INT'L L. (2004).

7. For a collection of essays exploring this theme, see generally id.

8. For analyses of the spread of international public authority, see generally JosÉ E. ALVAREZ, INTERNATIONAL ORGanizations as LAW-MAKERS (2005); DELEgating STATE POWERS: THE EFFECT OF TREATY REGIMES ON DEMOCRACY AND SOVEREIGNTY (Thomas M. Franck ed., 2000); THE EXERCISE OF PUBLIC AUTHORITY BY INTERNATIONAL INSTITUTIONS: ADVANCING INTERNATIONAL INSTITUTIONAL LAW (Armin von Bogdandy et al. eds., 2010). 
might have on it. International law is derivative in regards to legitimacy. International law derives its legitimacy from the consent of states. This understanding of the foundation of international law has significant implications for the interpretation and progressive development of international law. Insisting on a link to national institutions in the generation, interpretation, and enforcement of international legal norms becomes a central preoccupation..$^{9}$ From this perspective, the talk of constitutionalism beyond the state misleadingly tends to cover up both the legitimacy deficit of an international law in which the link to state consent becomes more attenuated, as well as the threat this constitutes to the achievements of domestic constitutionalism.

Conversely, Small c constitutionalists insist that the legitimacy of international law does not depend on tracing international legal obligations back to the specific consent of obligated states. Rather, they insist that the legitimacy of international law is not simply derivative, but to some extent stands on its own. Both in terms of operation and legitimacy, the international legal order can be described as an "autonomous" legal order that should be interpreted and progressively developed to better realize the constitutional values it is founded on.

At its heart, the debate about the constitutional character of international law should be understood as a debate about how to understand the conditions of constitutional legitimacy. Big $\mathrm{C}$ constitutionalists are right about two things. First, constitutionalism should be understood as a normatively ambitious project of establishing legitimate authority over persons that are ultimately conceived as free and equals. This indeed gives rise to the trinitarian formula of the constitutionalist faith: a commitment to human rights, democracy, and the rule of law. ${ }^{10}$ But there is deep and interesting disagreement about

9. This has been the common theme of all "Revisionist" writing on the law of foreign affairs in the United States. See generally the work of Curtis Bradley, John Yoo, Jack Goldsmith, and Eric Posner.

10. Note how this concept of constitutionalism is not shared by societal constitutionalists such as, most prominently, Gunther Teubner. See, e.g., GUNTHER TEUBNER, CONSTTTUTIONAL FRAGMENTS: SOCIETAL CONSTTTUTIONALISM AND GLOBALIZATION 1-3 (2012) (criticizing traditional constitutionalism and its limitations in addressing transnational constitutional challenges). Teubner's is a sociological, systems-theory informed understanding of constitutionalism. It is well-equipped to identify cohesively structured social practices and describe the dynamics and relationships between such practices. Societal constitutionalism provides a prism that helps normatively-focused constitutionalists develop a sociologically enriched understanding of the world they are trying to assess. But societal constitutionalists do not participate in the project of working out the implications of a shared normative commitment to the idea of free and equals governing themselves through law. They do not provide an account of constitutionalism that interprets the heritage of the French and American revolutions for the purpose of gaining a better normative 
how that commitment is to be understood in more concrete terms. Competing interpretations of the constitutional heritage of the French and American Revolutions as they relate to international law compete with one another. Both Big $\mathrm{C}$ and Small $\mathrm{c}$ constitutionalists share a common constitutionalist grammar in their understanding of the conditions of legitimate authority. They may both insist that a constitutional justification of authority requires public power to be legally constituted and constrained, appropriately participatory, and rights-respecting. They disagree, however, about how these ideas should be worked out when it comes to assessing the relationship between national and international law. They disagree on whether international law should be conceived in derivative terms. Is the consent of states the foundation of international law? Does international law derive its legitimacy from the consent of states? Should it be a core concern that international law is interpreted and progressively developed to ensure that national institutions, the sole conveyers of constitutional legitimacy, remain in charge? Big $\mathrm{C}$ constitutionalists are inclined to insist on all of these things, whereas international constitutionalists insist on a negative answer to all of these questions. They insist that a proper understanding of the constitutional tradition requires international law to be understood, interpreted, and progressively developed in a way that allows international legal and political practices to play a more independent role.

But what role exactly should that be, and how should it be justified in constitutional terms? Reading the literature, it is relatively clear that most international constitutionalists tend to favor more international law, stronger international institutions, more compulsory jurisdiction for courts, more participatory possibilities for individuals and members of an international civil society, more mechanisms ensuring respect for human rights by states, and so forth. However, much of this writing takes the form of relatively formal arguments analyzing treaties, court decisions, or legal documents generated by international institutions. International constitutionalists often assume the posture of conventional positivist analysts, even as they are believed to be engaged in a deeply important normative project. On a more abstract level they tend to be against, or want to move beyond, sovereignty and the state-indeed, the sovereign state is often the bete noir. They may

understanding of the world of law we inhabit, in order to move it closer to where it should be. As sociologists, Societal Constitutionalists bracket questions of justice. (Luhmann claimed that systems theory provided a way to overcome and move beyond questions of justice, which he referred to as "old-European."). Focusing on the conditions under which justice can be established between free and equal persons is, however, the core preoccupation of constitutionalist thinking in the tradition of the French and American Revolutions. 
instead insist on human dignity as the foundation of international law. ${ }^{11}$ And they may point to interdependencies and make functional arguments about the need to provide global public goods that states cannot provide by themselves. ${ }^{12}$ But whereas there is rich and theoretically sophisticated literature in normative constitutional theory about the basic institutions and ideas underlying domestic constitutionalism, as well as how these ideas and institutions connect to concrete issues and problems, there is relatively little equivalent literature that brings to bear normatively rich constitutionalist thinking in international law.

The following sections will begin with an argument that analyzes what exactly is wrong with Big $\mathrm{C}$ constitutionalism in order to develop some basic ideas about the foundations of public law in the constitutionalist tradition. Big C constitutionalists are right to connect the idea of constitutionalism to a normatively ambitious project of establishing legitimate authority. But the idea of sovereignty as ultimate authority-a conception of constitutionalism tied to the coercive institutions of the state and a conception of legitimacy and democracy reductively tied to the self-governing practices of "We the People"-is deeply misguided. It aggrandizes and misconstrues national constitutional practice and sells short legal and political practices beyond the state. It misconstrues the basic commitments underlying the constitutionalist tradition of the French and American Revolutions. This article will then analyze how national and international law have to be conceived, in constitutional terms, as mutually supportive and complementary. International lawyers are right to insist on the constitutional nature of international law. But they should acknowledge more openly that their construction is ultimately informed by a competing conception of legitimate authority, one that provides a different interpretation of the constitutionalist tradition, an interpretation that is directly in conflict with Big C constitutionalism and that is considerably more ambitious than Small c constitutionalism. These lawyers would do well to more strongly emphasize the deep interdependencies between national and international law.

11. See generally PATRICK CAPPS, HuMAN DIGNITY AND THE Foundations of INTERNATIONAL LAW (2009). The focus on human dignity as the foundation and purpose of Illinois was also shared by the New Haven School. See generally MYRES S. MCDOUGAL ET AL., HUMAN RightS AND WORLD PUBliC ORDER: THE BASIC POLICIES OF AN INTERNATIONAL LAW OF HUMAN DIGNITY (1980).

12. See generally ERNST-ULRICH PETERSMANN, INTERNATIONAL ECONOMIC LAW IN THE 21ST Century: Constitutional PluRalism and Multi-level Governance of INTERDEPENDENT PUBLIC GOODS (2012). 
International law is neither derivative, nor is it autonomous. National and international law form an integrative whole.

\section{AgAinst Big C CONSTITUTIONALISM AND FOR THE COSMOPOLITAN TURN IN CONSTITUTIONALISM}

Contrary to the precepts of $\mathrm{Big} \mathrm{C}$ constitutionalism, national constitutional legitimacy is not self-standing. The legitimacy of national constitutions is not only a matter between "We the People" and the national constitution. National constitutional legitimacy depends, in part, on how the national constitution is integrated into and relates to the wider legal and political world. Domestic constitutional law has to be embedded in the right way in an appropriately structured international legal system for it to be legitimate. One of the core purposes of international law is to create and define the conditions under which a sovereign state's claim to legitimate authority is justified. States have a standing duty to help create and sustain such conditions and an international legal system that is equipped to fulfill that function. The relationship between domestic and international law is neither one of derivation nor of autonomy, but of mutual dependence. National and international law are mutually co-constitutive. The constitutional legitimacy of national law depends, in part, on being adequately integrated into an appropriately structured international legal system. And the legitimacy of the international legal system depends, in part, on states having an adequate constitutional structure. The standards of constitutional legitimacy are to be derived from an integrative conception of public law that spans the national-international divide.

There can be no self-standing national constitutional legitimacy because the practice of constitutional self-government within the framework of the sovereign state raises the problem of justice-relevant negative externalities.

The fact of interdependence has often been invoked as a generic argument in favor of international law. But as will become clear, interdependence itself is not an argument against Big $\mathrm{C}$ constitutionalism or for the development of an international law that has the features Small c constitutionalists focus on and Big $\mathrm{C}$ constitutionalists tend to be critical of. It may be true that international law is a means to reap the benefits of better cooperation and coordination between interdependent actors. But this would merely provide a functional argument for states to sign up for certain kinds of international cooperative endeavors. It would not, without further 
argument, undermine the claim to authority that is implicit in Big $\mathrm{C}$ constitutionalism.

The issue is different, however, when not just any externalities, but justice-sensitive externalities are in play. National sovereigns can claim no legitimate authority to address questions involving justice-sensitive externalities unilaterally. Given the fact of reasonable disagreement between states about how those externalities should be taken into account, any claim by one state to be able to resolve these issues authoritatively and unilaterally amounts to a form of domination. It is the point and purpose of international law to authoritatively resolve these concerns by way of a procedure that involves the fair participation of relevantly effected stakeholders, and it is the duty of states to support and sustain the development of an international law that is able to effectively fulfill such a function. In the following, I will first discuss how the presence of justice-sensitive externalities undermines claims to legitimate national constitutional authority. I will then focus more closely on three different kinds of externalities, the normative concerns they raise, and the structure that international law needs to have to be able to address these concerns adequately.

\section{A. Why Do Justice-Relevant Negative Externalities Undermine Claims to Legitimate Authority?}

There is no doubt that a wide range of national policy choices implicates justice-sensitive externalities. Consider the following four examples: first, a state decides to intervene militarily in another state; second, a state decides to embrace nuclear power stations not far from state borders and decides on nuclear safety standards that adjacent states claim are dangerously low; third, a state decides what level of carbon-dioxide emissions strikes the right balance between concerns about global warming and economic competitiveness; and, fourth, a state decides how to allocate resources and sets priorities for law enforcement to either clamp down or not to clamp down on transnational organized crime. In all of these cases, outsiders may be affected in a way that raises concerns about whether their interests have been appropriately taken into account or whether others have unjustly burdened them.

Below, I will describe and more closely analyze different kinds of externalities and the justice-related problems they raise. Here, the question is what follows from the fact that state policies often have justice-sensitive external effects. What follows is, first, that a state has a duty to be aware of those externalities and take them into consideration when conceiving and implementing national policies to 
avoid doing injustice. This requires state actors to conceive of themselves as something more than just participants in a practice of national self-government focused on and concerned with how public policies affect national constituents. Instead, when enacting policies that generate justice-sensitive negative externalities, states have a duty of justice to also act as trustees of humanity. ${ }^{13}$ For a state's policies to be just, they need to adequately take into account the legitimate interests of effected outsiders.

But that alone is not enough. There is a second consequence. The range of questions over which a state can plausibly claim legitimate authority is limited to questions that do not raise issues of justice-sensitive externalities. A constitution established by "We the People" can only claim legitimate authority over a domain in which there are no justice-sensitive externalities. If a state does not accept the restriction of its authority and help support a constitutional system of international law that is adequately equipped to address these issues, it would stretch its claim to legitimate authority and, in effect, insist on a relationship of domination with regard to those who are externally affected. It is not sufficient for a state to attempt to do justice to outsiders by way of respecting their legitimate concerns in the policy-formation process. The existence of external justice concerns challenges the authority of "We the People" and limits the authority of national constitutions. Furthermore, it grounds the obligation of a national community to support, help develop, and subject itself and its constitutional system to the authority of an appropriately structured system of international law, which defines the boundaries of legitimate sovereign authority.

To understand this concept, it is useful to think about the grounds for legitimate authority in the domestic context. Under what might be called the "standard account" of legitimate authority within the constitutionalist tradition of the eighteenth century, ${ }^{14}$ the starting point is the problem of establishing just relations between free and equal persons. The establishment of just relations between people is continually hampered by two problems. Because of these problems, it is

13. Eyal Benvenisti, Sovereigns as Trustees of Humanity: On the Accountability of States to Foreign Stakeholders, 107 AM. J. INT'L L. (forthcoming 2013) (manuscript at 7-8), available at http://ssrn.com/abstract $=1863228$. See also Anne Peters, Humanity as the A and $\Omega$ of Sovereignty, 20 EUR. J. INT'L L. 513 (2009) (arguing that the concept of sovereignty should derive not from the state as such but from the rights and interests of humanity).

14. These themes are central to the understanding of law in the political philosophy of Hobbes, Rousseau, and Kant, among others. For a useful overview of these issues, see Samantha Besson, The Morality of Conflict: Reasonable DisagreEment and the LAW 121-203 (2005). 
not sufficient for each actor to publicly profess allegiance to justice, but requires something more-the subjection to constitutional authority. Why is that necessary? Can we all not just agree to do the right thing and get along?

First, there is the problem of motivation. By themselves, individual actors might not always be motivated to do what justice requires when they experience a conflict between what they might want to do and what they might recognize as an obligation of justice. The institutionalization of a constitutional system seeks to add nonmoral incentives-the threat of institutionalized sanctions of some kind-to support and stabilize justice-respecting behavior. ${ }^{15}$ The threat of sanctions has a double role in this regard. First, the addressee of the law has an additional incentive not to defect from a commitment to justice in the face of what may appear to be other competing interests because of the threat of sanctions. The threat of sanctions makes it easier to fight weakness of the will and the temptation to ignore requirements of justice. Second, the threat of institutionalized sanctions provides an assurance of reciprocity. The threat assures that an actor seeking to comply with duties of justice will not end up the "sucker" when, in a reciprocal relationship, the other side takes advantage of justice-compliant behavior but refuses to comply with its obligations.

Second, there is an epistemic problem. Even if we assume all relevant actors to be motivated in the right way, they might still disagree about what justice actually requires. There is no procedure that guarantees that even well-informed and appropriately disposed intelligent actors agree on specific questions of justice. Given disagreement over questions of justice, appropriately structured procedures need to be put in place to authoritatively determine what claims of justice are to be recognized as valid. The alternative would be to have the more powerful side dictate and enforce its conception of justice against the weaker side. That, however, would be a form of domination. It would privilege one side over the other without good reason. ${ }^{16}$ The actors are, therefore, under an obligation to establish and subject themselves to a system of constitutional authority that provides appropriately impartial and participatory procedures to resolve these disagreements and ensures that the results are not unreasonable, but are justifiable to all concerned. These, in a highly stylized form, are some of the key steps for the justification of legitimate authority within the liberal-democratic constitutionalist tradition.

15. See id.

16. Reasons simply invoking facts about power relationships do not count as good reasons in the constitutionalist tradition, and both sides, we are assuming, claim to have justice on their side. 
If the arguments relating to justice-sensitive externalities that are standard fare in philosophical accounts of the duty of individuals to help establish and subject themselves to appropriately structured constitutional authority on the state level are correct, the problem replicates itself in the relationship between states. ${ }^{17}$ Questions of justice also arise between independent self-governing actors. These questions often become contentious because of the interplay between mixed motivations and epistemic problems, leading to disagreement and distrust. The history of foreign policy-even of powerful liberal democracies-provides ample illustrations of disregard and bias against outside interests, even if it were the case that liberal democracies do a better job of taking into account those interests than other forms of government. ${ }^{18}$ Given that statesmen have an incentive to focus on the concerns of national constituents, the structural bias of national political processes with regard to questions of justice-sensitive externalities is obvious enough. Furthermore, even though states are obligated to do justice with regard to individuals whether or not there are appropriate assurances of reciprocity, ${ }^{19}$ there are many obligations under international law that exist only subject to the condition of reciprocal compliance. ${ }^{20}$

Furthermore, the kinds of justice questions that arise in relation to negative externalities of national policies are clearly issues on which there is often reasonable disagreement. Even if reasonable people might agree that the appropriation of territory by way of military force is a violation of another sovereign's right, what kind of measures may be used to retaliate against violations of legal obligations by another state? What kind of weapons may they seek to acquire? What kind of counterterrorism effort is minimally necessary to meet protective obligations? What level of pollution of a river is acceptable upstream given downstream usage? What level of carbon-dioxide emissions is

17. For the first development of this, see Immanuel Kant, Perpetual Peace 128-36 (M. Campbell Smith trans., 1917) (1795).

18. It is reasonably well-established that democracies tend not to go to war with each other. For an overview of the debate and literature relating to the "Democratic Peace" thesis, see generally SteVen PINKER, The BetTer ANGels of our Nature: Why VIOLENCE HAS DECLINED (2011). Moreover, there seems to be a correlation between liberal democracies, opening up markets to participate in the global economy, and the degree of multilateral legal integration as reflected in membership in international institutions. Id.

19. This is recognized also under positive international law with regard to certain obligations. See, e.g., Responsibility of States for Internationally Wrongful Acts, G.A. Res. 56/83, art. 50, Annex, U.N. GAOR, 56th Sess., U.N. Doc. A/56/49 (Vol. 1) (Dec. 12, 2001).

20. In case of noncompliance, a state can take countermeasures, in the form of nonperformance of its obligations vis-à-vis the noncompliant state. See, e.g., id. arts. 49-53. 
acceptable in light of the consequences of global warming? These kinds of questions give rise to debates in which actors might reasonably disagree about what exactly justice requires in a given context.

Because of the pervasiveness of reasonable disagreement, these are not the kinds of issues that a state's constitutional system, no matter how internally democratic, can claim legitimate constitutional authority over. Claiming authority to resolve questions of justice concerning outsiders, who per definition have no equal standing in the domestic policy formation process, is an act of domination. The enforcement of a conception of justice by a powerful actor or a hegemonic coalition of actors against others making competing claims is an act of domination if those hegemonic actors refuse to subject themselves to an impartial procedure providing equal participatory opportunities for those whose reasonable justice claims are implicated. With regard to issues concerning justice-sensitive externalities, each state is under a standing obligation to support, help further develop, and subject itself to a constitutional system of international law that is equipped to authoritatively address these issues. Such a system would have to provide an impartial and appropriately participatory procedure to resolve these issues in a way that is reasonable and justifiable to all concerned. The point of such a system of international law is to define the domain over which states can legitimately exercise sovereignty and "We the People" can claim self-governing constitutional authority.

\section{B. Three Kinds of Externalities}

Given the centrality of justice-sensitive externalities for understanding the limits of national constitutional authority and the purpose of international law, a closer analysis of the concept and its main practical manifestations are in order. More specifically, I will distinguish between three kinds of externalities. Each type of externality raises distinct normative concerns and accounts for specific structural features of international law. Here, it must suffice to describe these externalities, the kinds of justice concerns they raise, and the basic features that international law must have to adequately address them. 


\section{Establishment of borders}

The first kind of justice-sensitive negative externality is structural. It is linked to the fact that a people governing itself within the institutional framework of the state requires the establishment of borders. The claim to self-government-to use the territory within the state borders as is deemed desirable by "We the People" organizing their lives together-has an external corollary in the claim to a collective right to exclude others from crossing the borders and entering. ${ }^{21}$ States generally claim a sovereign right to freely determine whom they let in and whom they refuse to let in. Importantly, this restricts the liberty of those intending to cross a state boundary and seeking to move to the territory of another state, whether to find a better life for themselves or any other reason. How can such exclusion be justified? What justifies the coercive force someone might encounter at the border when they seek to enter without meeting whatever requirements happened to have been established nationally?

The claim to sovereignty over territory by "We the People" can be, and has been, analogized to the claims to property over land by individuals in a domestic society, claiming the right to exclude others from its use. Generally, arguments in favor of a world divided into distinct and separate sovereign states focus on an array of benefits for assigning special responsibility to a group of persons to a specific piece of land.22 This is not the place to engage the rich literature on these issues. But any successful justification for a right to exclude outsiders seeking entry satisfies the Lockean proviso that there has to be "enough and as good left in common for others." 23 Even though every

21. This issue has spurned a rich literature in recent years. See generally AYELET SHACHAR, THE BIRTHRIGHT LOTTERY: CITIZENSHIP AND GLOBAL INEQUALITY (2009); David Miller, Immigrants, Nations, and Citizenship, 16 J. PoL. PHIL. 371 (2008); Mathias Risse, On the Morality of Immigration, 22 ETHICS \& INT'L AFF. 25 (2008).

22. See generally DaVid MilleR, ON NaTiONALITY (1995); John RaWLS, The LaW OF PEOPLES (1999).

23. Robert NozicK, ANARCHY, STATE, AND Utopia 175 (1974). This Lockean Proviso was reintroduced into the modern debate about the original appropriation of property by Nozick's work and refers to John Locke's argument in the Second Treatise of Government that the recognition of a right to appropriation of property did not do injustice to others now precluded from making use of the appropriated land. Id. at 174-82. Locke argues as follows: "Nor was this appropriation of any parcel of land, by improving it, any prejudice to any other man, since there was still enough, and as good left; and more than the yet unprovided could use. So that, in effect, there was never the less left for others because of his enclosure for himself: for he that leaves as much as another can make use of, does as good as take nothing at all. No body could think himself injured by the drinking of another man, though he took a good draught, who had a whole river of the same water left him to quench his thirst: and the case of land and water, where there is enough of both, is 
appropriation of property is a diminution of another's rights to it, it is justifiable for so long as it does not make anyone worse off than they would have been without the possibility of such appropriation. The standard of "as good" in the context of claiming exclusion from territorially-based practices of self-government requires that the person denied entry must have access to the territory of a state where, at the very least, his or her rights are not violated in a serious way. In order to justify excluding someone from a state, that person must have access to some other state that does not violate his or her rights. Anything else could not plausibly qualify as good enough in the relevant sense. If State A meets this requirement, it succeeds in creating the preconditions for the legitimate assertion of State $B$ to exclude those individuals from State A seeking entry into B. When, in a concrete situation, an individual finds herself subject to a state that clearly does not fulfill its sovereign obligations to respect, protect, and fulfill her rights and then decides to exercise her right to exit that state and to seek entry elsewhere, it is not clear how the exclusion of such a person could be justified.

Thinking about borders and the right to exclude in this way helps to highlight the importance of two core features of international law. On the one hand, international law seeks to create the conditions for the legitimate exercise of the right of a sovereign to exclude. All states are required by international law to respect, protect, and fulfill the human rights of those subject to their jurisdiction. On the other hand, international law limits the sovereign right to exclude in cases where these conditions are not met, particularly in the case of refugees. ${ }^{24}$ Note how this way of conceiving of international human rights law provides a hard ground for why international law concerns itself with how states relate to their citizens. We must strive to ensure that rights are respected everywhere, not just to promote solidarity with all members of the human community, but also because it is in our interest to ensure that the necessary preconditions for justifying our national exclusionary practices are met.

perfectly the same." JOHN LOCKE, SECOND TREATISE OF GoverNMENT $\S 33$ (C.B. Mcpherson ed., Hacket Publ'g Co. 1980) (1690).

24. See Convention Relating to the Status of Refugees, art. 1, July 2, 1951, 189 U.N.T.S. 137. Art. 1 as amended by the 1967 Protocol of United Nations Convention Relating to the Status of Refugees defines a refugee as a person who, "owing to well-founded fear of being persecuted for reasons of race, religion, nationality, membership of a particular social group or political opinion, is outside the country of his nationality and is unable or, owing to such fear, is unwilling to avail himself of the protection of that country; or who, not having a nationality and being outside the country of his former habitual residence ... is unable or, owing to such fear, is unwilling to return to it." Id. 


\section{Justice sensitive externalities of national policy}

Besides the fact that states establish borders and claim the right to exclude, there are justice-relevant externalities related to states implementing national policies, burdening outsiders with harms, and threatening harm or risks. These externalities range from the obvious to the more subtle. On the obvious end of the spectrum, there are states that embrace an aggressive, expansionist foreign policy. An imperial policy of domination and expansion subverting the political and territorial independence of neighbors is obviously not justified, even when such a policy enjoys widespread democratic support in the aggressor state and that state has a well-structured national constitutional system. Less obvious examples raise significantly more pervasive concerns and do not concern foreign policy directly. Think of the establishment of nuclear power plants near the border with insufficient safety standards applied by the jurisdiction that these reactors are stationed in. Or, think about carbon-dioxide emission standards that contribute to global warming. While the detrimental effects of these standards may be moderate in the polluting jurisdiction, that pollution may lead to severe droughts that cause starvation, severe flooding that results in the forced relocation of millions, or even the wholesale sinking of island-states in other jurisdictions. Less dramatically, imagine an upriver riparian state polluting a river to such an extent that it imposes severe harms downstream within the territory of the downriver state. Finally, and more subtly, extraterritorial effects raising justice concerns may also be connected to states failing to exercise their responsibility to prevent their territory from being used as a base to organize, plan, and inflict harm in other jurisdictions by other actors. Justice concerns are not merely raised by negative externalities of state action, but also by omissions that result in the failure to realize positive externalities when the state has a responsibility to act. Here, the issues raised include failing to undertake adequate counter-terrorism efforts by effectively granting safe harbor to terrorist organizations or failing to crack down on other forms of organized crime.

Given that these are areas in which states lack legitimate authority to effectively control what may or may not be done, there is no injustice done to states when they are subjected to legal obligations without having consented to them. On the contrary, there are deep legitimacy questions connected to the capacity of individual states to effectively veto the emergence of universally binding obligations in contexts where the behavior of an individual state raises justice-sensitive externality concerns. Thankfully, international law has developed capacities to 
generate universally binding legal obligations that overcome the blocking power of individual states that refuse to give their consent. With regard to the use of force and questions of peace and security, the U.N. Security Council has interpreted its competencies broadly and functions, albeit often unsatisfactorily, as a world legislator operating by qualified majority vote in areas concerning threats to international peace and security. ${ }^{25}$ Furthermore, in many cases involving these types of concerns, ${ }^{26}$ international courts and tribunals have interpreted the requirements for customary international law (CIL) in a way that reflects the underlying purpose of international law. When justice-sensitive externalities are in play, judges tend to interpret the requirements of CIL as if these requirements reflect the idea of a decentralized informal quasi-legislative qualified-majoritarian process, not the idea of implied consent by states. ${ }^{27}$ The real problem in this area is not that there is no state consent requirement for obligations to be generated. There is no problem when, instead of consent, there is a fair procedure involving adequate participatory procedures for states that can generate new obligations. The real problem is the extent to which powerful states remain in a position to veto jurisgenerative efforts. The veto claimed and exercised by the five permanent members in the Security Council raises more legitimacy issues than any erosion of the consent requirement. To address these concerns, creative interpretative proposals aimed at qualifying the veto right and narrowing the capacity of individual states to block otherwise universally binding decisions point in the right direction. ${ }^{28}$

25. See Stefan Talmon, The Security Council as World Legislature, 99 AM. J. INT'L L. 175,175 (2005).

26. See Anthea Elizabeth Roberts, Traditional and Modern Approaches to Customary International Law: A Reconciliation, 95 AM. J. INT'L L. 757 (2001) (arguing that the standards for determining whether CIL exists with regard to a particular issue might be sensitive to the particular function that international law needs to fulfill in the respective area). For similar ideas focused on the role of national courts engaging international law more generally, see also Eyal Benvenisti, Reclaiming Democracy: The Strategic Uses of Foreign and International Law by National Courts, 102 AM. J. INT'L L. 241 (2008).

27. The legitimating idea of consent of states in international law could be analogized to the idea of consent in domestic constitutional theory. Individuals are subject to the laws of the land, whether or not they have explicitly or implicitly consented to them. Consent is only relevant in the sense that liberal political philosophy refers to: the idea of "reasonable consent" remains an operative ideal standard for assessing claims of justice. Actual consent matters only in a limited domain, where individuals are in authority and can control the obligations they have with regard to others: the domain of private law contracts.

28. See, e.g., Peters, supra note 13, at 539-40 (arguing that a veto cast under certain circumstances should be regarded as null and void). 


\section{Externalities of national policies that do not raise justice concerns}

All the examples above describe externalities that raise justice concerns. A wide range of externalities, however, do not. Outsiders have no claim of justice against a state's political community to generally take into account their well-being when making a decision that has external effects. Outsiders have a right not to be unjustly harmed by a state, but those governing themselves within the framework of the state have a right not to be required to make themselves an instrument of the well-being of others. Much could be said about why this is so and what exactly follows from this, ${ }^{29}$ but here it must suffice to put forward a couple of basic distinctions and examples for illustrative purposes.

First, the failure to realize positive externalities-an omission by a state-is a justice concern only in cases where there is a positive duty of justice for the state to act. A state is under a positive duty, for example, to ensure there are no harms emanating from its territory. ${ }^{30}$ Here, the relevant externalities concern justice claims by outsiders. ${ }^{31}$

There is no general duty of a state, however, to take into account and further the welfare of outsiders in the same way they would insiders. When debating whether more money should be spent on social security to strengthen those that are weakest in domestic society, it is not plausible to insist that first money has to be spent to raise the level of those worst off globally up to that of those worst off nationally. It does not constitute unjustified discrimination that national social security benefits are not available to every person on the globe. Nor is a state acting in a way that raises justice concerns when it adopts a national economic policy that is focused on increasing national welfare, but that has a more dubious global effect. States are not under a general duty to ensure that outsiders benefit as much from state policies as nationals. They are trustees of humanity only to the extent outsiders can make plausible claims of justice that a state is required to respect. Beyond that, states have special obligations toward their own citizens and rightly make their well-being the paramount concern.

29. For a discussion of the role of deontological restrictions in various areas of the law, see generally Mattias Kumm \& Alec D. Walen, Human Dignity and Proportionality: Deontic Pluralism in Balancing (N.Y. Univ. Sch. of Law Pub. Law \& Legal Theory Research Paper Series, Working Paper No. 13-03, 2013), available at http://ssrn.com /abstract $=2195663$.

30. For a good overview on the way this principle operates in the area of environmental international law, see generally JULIO BARBOZA, THE ENVIRONMENT, RISK AND LIABILITY IN INTERNATIONAL LAW (2011).

31. This is also true when those harms are brought about not directly by state action, but by private actors, such as terrorists or other forms of organized crime. 
Second, even the infliction of negative externalities does not always constitute a justice-sensitive externality. There is no injustice done to outsiders, for example, when a state engages in protectionist policies and denies or prohibitively taxes market access of certain goods and services. There is no justice claim against another political community to make itself a means for realizing economic benefits for others. Even if a state, at time $\mathrm{T} 1$, opened its borders for certain trades and, later, at time T2, unilaterally closed them again, thus imposing severe losses on outside traders who had relied on making such trades, these are not negative externalities that raise justice concerns. Just like a shopkeeper has no claim of justice against a patron who decides from one day to the next to no longer patronize his shop, the importer has no claim to justice against a state deciding to close its borders to a certain kind of trade. In these types of cases the actions of one state merely changes the circumstances another state finds itself in. ${ }^{32}$

When there is a high level of interdependence-situations in which subjects mutually find themselves subjected to the infliction of externalities by outsiders-states have an interest to coordinate policies and cooperate with one another to maximize the welfare of their constituents and ensure pareto-optimal policies. This is, of course, what most countries have done across a wide range of goods and services to mutually profit from more open markets within the context of the World Trade Organization (WTO) or other regional trade regimes. Once a country has legally committed itself bi- or multilaterally to grant access to certain goods and services, the situation changes. In such a context, the negative externalities connected to a failure to comply with contractual obligations generally constitute justice-relevant harms. But they do so only because of violations of agreed commitments and not independently from such commitments. In such a context, voluntary legal commitments are constitutive of plausible justice claims.

This, then, is the proper domain of consent-based interactional treaty law. Here, treaties are the functional equivalent of private law contracts in domestic law. Consent is not the foundation of international law, but there is a domain in which sovereign states can claim to be free to do as they deem fit and subject themselves only to obligations they have freely accepted. There is a domain in which consent is rightly regarded as constitutive of legal obligations. This is the domain over which a sovereign has authority.

Note, however, that the exact scope of that domain may not only be contested, but may even be unstable. Whether externalities are justice

32. See, e.g., Arthur Ripstein, Force and Freedom: Kant's Legal and Political PHILOSOPHY (2009). 
sensitive is not always a simple issue. Agreements of a certain density and duration may well become the source of associational moral duties that go beyond the specific terms of the agreement. The more dense and more demanding mutually agreed upon frameworks of cooperation are, the more demanding the justice obligations that flow from such a practice are. ${ }^{33}$ What justice requires is, to some extent, practice dependant. ${ }^{34}$

In practice, this means that, much like in private contract law, freedom of contract is and should be constrained and structured by other, not necessarily consent-based, legal norms seeking to further justice or welfare-enhancing policies. It would suggest, furthermore, a hierarchical relationship between international legal obligations understood to fall within the domain of this private law paradigm and international legal obligations more appropriately interpreted as quasi-legislative. But, whereas in domestic law, contracts between individuals are generally void when they are in violation of general legal rules, the situation is more complex in international law. While states cannot validly enter into treaties violating ius cogens norms, ${ }^{35}$ all duties established under the U.N. Charter take precedence over other treaty obligations, ${ }^{36}$ and bilateral treaties cannot change the general legal obligations a state is under with regard to third parties. ${ }^{37}$ Yet, there is no general rule that invalidates bilateral treaties that are in violation of quasi-legislative multilateral treaties or rules of customary international law seeking to realize global public goods.

But notwithstanding these and other complexities, which could barely be gestured to here, the point is that not all negative externalities of national policies raise justice concerns. Interdependence alone is not itself sufficient to establish the duty of a national community to take into account the effects of their actions on outsiders. Only justice-relevant externalities can do so. ${ }^{38}$

33. See generally Andrea Sangiovanni, Solidarity in the European Union: Problems and Prospects, in PhILOSOPHICAL Foundations of EUROPEAN UNION LaW 384 (Julie Dickson \& Pavlos Eleftheriadis eds., 2012).

34. See Miriam Ronzoni, The Global Order: A Case of Background Injustice? A Practice-Dependent Account, 37 PHIL. \& PuB. AFF. 229, 230-31 (2009). See also Sangiovanni, supra note 33 , at 409 , n.70.

35. Vienna Convention on the Law of Treaties art. 53, May 23, 1969, 1155 U.N.T.S. 331 [hereinafter Vienna Convention].

36. U.N. Charter art. 103; Vienna Convention, supra note 35, art. 30, I 1.

37. Vienna Convention, supra note 35, art. 30, ๆ1 4-5.

38. How exactly this distinction is best fleshed out and made operable lies beyond the scope of this article. See generally RIPSTEIN, supra note 32. 


\section{CRITICISMS AND THE CHALlENGE OF SOCIETAL CONSTITUTIONALISM}

The idea of self-government of free and equals lies at the heart of the tradition of liberal-democratic constitutionalism. The guiding ideal of global order this gives rise to is a world of liberal democratic constitutional states, collectively subjected to the authority of international law. ${ }^{39}$ The point of international law is to authoritatively define the conditions under which sovereigns can govern themselves as well as provide the legal space for sovereigns to coordinate their activities and cooperate as they deem fit. The relationship between domestic and international law is neither one of derivation nor of autonomy, but of mutual dependence. National and international law are mutually co-constitutive. The constitutional legitimacy of national law depends, in part, on being adequately integrated into an appropriately structured international legal system. And the legitimacy of the international legal system depends, in part, on states having an adequate constitutional structure. The standards of constitutional legitimacy are to be derived from an integrative conception of public law that spans the national-international divide.

What this article has tried to do is to provide a rough general outline for the reconstruction of the foundations of contemporary public law. Many of the core structural features of international law can be explained and justified by reference to the cosmopolitan construction of public law described here: the role of human rights law, the emergence of multi-lateral global governance practices, the emancipation of international law from the strictures of state consent, the functional reconceptualization of sovereignty in terms of responsibilities and participation, as well as the constructive constitutional engagement of liberal democracies with international law. Yet, these are exactly the features that Big $\mathrm{C}$ constitutionalists point to as symptomatic of international law's legitimacy deficit, features of international law that threaten democratic constitutionalism. But all of that is mistaken. Tying together a commitment of self-government, democracy, the state, sovereignty, and supreme legal authority in this way, Big C constitutionalism misguidedly aggrandizes the authority of sovereign states to the detriment of international law. Those who engage international law through the prism of such a theory seek to interpretatively connect international law more closely to the consent of states and the enforcement of international law to the political endorsement of national political majorities. Doing so not only assumes

39. See KanT, supra note 17. See also Anne-Marie Slaughter, International Law in a World of Liberal States, 6 EUR. J. INT'L L. 503 (1995). 
that "We the People," organizing themselves within the boundaries of a state, can establish the kind of self-standing authority that they cannot. It also prevents international law from fully developing its potential to help create and define the preconditions for the exercise of legitimate sovereignty. Big $\mathrm{C}$ constitutionalism is a misguided interpretation of the constitutionalist tradition. It sells short the cosmopolitan perspective inherent in the idea of self-government of free and equals and misunderstands the demanding task of international law-to first establish the conditions under which a state's claim to sovereignty can be legitimate.

As is appropriate for a reconstructive account of the foundations of existing international law, the assumptions underlying the argument presented here are largely conventional. The argument takes for granted a commitment to the principle of sovereign equality of states. It does not engage the idea of a world state or any other institutionally transformative project, but takes as a given the commitments to self-government and sovereign equality as they are inscribed in a number of foundational norms in international law.

Critics may charge that the focus on the state misses fundamental features of actual legal practice. Societal constitutionalists in particular might point to forms of sectorial private ordering in the world economy that are not captured by what remains a state-focused account of public law. ${ }^{40}$ Is it a coincidence that the paper does not mention any of the genuinely constitutional questions relating to data-gathering of major Internet companies, the regulatory structure of the banking system, or the legitimacy issues arising out of the emergence of a largely state-free administrated system of lex mercatoria? The response to this challenge is twofold.

First, questions of private ordering do indeed raise constitutional issues. When states establish global markets though bilateral and multilateral treaties, they face a challenge to ensure that economic practices taking place within the framework of private contractual and self-regulatory norms do not develop destructive tendencies that unjustly impose costs on outsiders. The financial crisis from 2008 onwards, and the regulatory responses that have followed, should indeed be regarded as a challenging constitutional case study for the assessment of global private ordering. Societal constitutionalists are right to insist that traditional constitutionalists, even those writing about international law in constitutionalist terms, tend to neglect questions of private ordering.

40. See TEUBNER, supra note 10 , at 8-9. 
I am more skeptical and am not sure how to understand the claim made by Teubner that these challenges present themselves and should be thought about as existing outside of the institutionalized sector of politics. ${ }^{41}$ Why is the challenge not to appropriately institutionalize adequately participatory political processes that allow for these issues to be addressed? Why would the kind of constitutionalist approach alluded to here not provide the right kind of critical conceptual framework? Take as an example the banking crisis. In part, the crisis was the result of bad domestic regulation, which, in principle, can be fixed by good domestic regulation. This is simply a case of policy failure. Of course, given the global structure of financial markets, the significant externalities of systemic banking failures in major economies, and collective action problems in the context of regulatory competition, the case for state cooperation and partial establishment of international standards or guidelines is strong. This is something the Basel Committee has done, the G-20 has discussed but failed to do, and the European Union has been actively pursuing. ${ }^{42}$ Of course there is much that could be said in assessing the adequacy of these venues and the procedures used from a constitutionalist perspective. Furthermore, any critical perspective would highlight the mistaken economic assumptions that have informed deregulation and models of risk-management in previous decades, as well as point to the capture of regulatory institutions by banks and a global banking class. All of this is clearly of great importance. What is less clear is how the banking crisis, or other questions relating to the constitutional structure of private order, challenges the kind of constitutional perspective developed here..$^{43}$

There are a number of other central issues the article has not grappled with. It has not spelled out exactly what the consequences of embracing the integrated conception of public law are for the

41. Id. at 1-14.

42. The Third Basel Accord (or Basel III) is a global, voluntary regulatory standard on bank capital adequacy, stress testing, and market liquidity risk. It was drawn up by the Basel Committee on Banking Supervision after the financial crisis in 2010-2011. In June 2012, the EU Commission introduced a proposal for a Directive establishing a framework for the recovery and resolution of credit institutions and investment firms, allowing for troubled financial institutions to be wound down. See Proposal for a Directive of the European Parliament and of the Council (COM(2012) 280/3), EUR. COMM'N, available at http://ec.europa.eu/internal_market/bank/docs/crisis-management/2012_eu_framework/CO M_2012_280_en.pdf.

43. For a discussion of the European financial crisis informed by the constitutionalist paradigm defended here, see Mattias Kumm, What Kind of a Constitutional Crisis Is Europe In and What Should Be Done About It? (Soc. Sci. Research Ctr. Berlin, Discussion Paper No. SP IV 2013-801, 2013), available at http://bibliothek.wzb.eu/pdf/2013/iv13-801.pdf (the report was requested by and was part of a testimony before the European Parliament's Committee on Constitutional Affairs). 
interpretation and progressive development of international law in any particular domain. It has not traced the implications of an integrative conception of constitutionalism for the adequate structure of the constitutional law of foreign affairs. ${ }^{44}$ It has not made much of what is often described as the fragmentization of international law, with different legal regimes following their own internal rationality with relative disregard for the outside. Nor has it addressed the question about whether and on what grounds it is plausible to believe that an international law that meets constitutionalist requirements can be effective. More specifically, it has not addressed the question of what follows from the fact that the world of states is not confined to established liberal democracies, but also includes powerful and less powerful authoritarian regimes, new and old democracies struggling with authoritarian nationalist tendencies, developing democracies with deep postcolonial suspicions of an ambitious international law, and a considerable number of failed or failing states. These are important questions that need to be addressed.

The point of this article, however, is considerably more modest. It seeks to discredit certain basic widespread ideas relating to the self-standing nature of domestic constitutional authority, tying together "We the People", self-government and state sovereignty, that have shaped and continue to shape the legal imagination of constitutional lawyers. Those who embrace these ideas tend to settle into a dogmatic slumber of self-congratulatory hubris with regard to the achievements of national constitutionalism, while promoting skepticism about international law. They attribute legitimacy to domestic constitutional practices that should raise concerns about domination and disregard of outsiders' claims. They impose limits on what international law might become in the name of deeply misunderstood ideas of democratic legitimacy. And they fail to take seriously international law for what it already is-an integral part of our highly imperfect constitutional universe.

44. See Mattias Kumm, The Cosmopolitan Turn in Constitutionalism: On the Relationship Between Constitutionalism in and Beyond the State, in RULING THE WORLD? CONSTITUTIONALISM, INTERNATIONAL LAW, AND GLOBAL GOVERNANCE, supra note 1, at 258. 